\title{
The Impact of Karkheh Dam Construction on Reducing the Extent of Wetlands of Hoor-Alazim
}

\author{
Samira Fuladavand ${ }^{1}$, Gholam Abbas Sayyad ${ }^{2}$ \\ ${ }^{1}$ Faculty of Agriculture, Shahid Chamran University of Ahvaz, Ahvaz, Iran \\ ${ }^{2}$ Department of Soil Science, Faculty of Agriculture, Shahid Chamran University of Ahvaz, Ahvaz, Iran
}

Email address:

Fuladvandsamira@yahoo.com (S. Fuladavand)

\section{To cite this article:}

Samira Fuladavand, Gholam Abbas Sayyad. The Impact of Karkheh Dam Construction on Reducing the Extent of Wetlands of Hoor-Alazim. Journal of Water Resources and Ocean Science. Vol. 4, No. 2, 2015, pp. 33-38. doi: 10.11648/j.wros.20150402.11

\begin{abstract}
Hoor-Alazim wetland in the southwest part of Iran at Khozestan province is located in Iran and Iraq borderline. The wetland extent depends on the entering river sediments and its supply. Hoor-Alazim is affected by the torrential sediments of rivers such as Tigris and Euphrates in Iraq and Karkheh in Iran. By 1998, Iran has started to exploit from the largest dam on Karkheh River, this river is one of the largest watery sources in Hoor-Alazim wetland. To supply with water of the dam caused to decline the quantity of entering water to the wetland and following it, the wetland extend has been reduced remarkably. Although various studies have been performed about the Hoor-Alazim wetland and it's expansion, no study has been yet conducted about the quantity of the entering water to the wetland. Therefore, this study aimed to examine the quantity (discharge and rainfall) entering water to the wetland during a certain statistical period in 3 hydrometric stations of Karkheh watershed basin (Hufel, Neisan, Hamidieh). To achieve the purposes of this research, researchers used the recorded data and information from the Khuzestan Water and Power Authority during the last 40 years using SPSS, GIS, and RS. Also, these influenced the wetland expansion and also finally the dust production in Ahvaz city was examined. Results from this study showed that the main factor which reduced wetland expansion is the reduction of entering water to it caused by the Karkheh River drainage. Despite the rain rate in the recent years which hadn't changed significantly, the amount of the entering water to the wetland was reduced. According to the results, the wetland expansion has changed from $900 \mathrm{~km}^{2}$ by 1991 to about $300 \mathrm{~km}^{2}$ by 2008 .
\end{abstract}

Keywords: Dam Construction, Karkheh Dam, Wetlands of Hoor-Alazim

\section{Introduction}

The water shortage in dry areas has negatively affected welfare, economic and politic practices. Population growth and increased public demands for new agricultural lands have led to the policy of increasing agriculture and performing projects related to the water resources like dam construction and water transportation in order to increase agriculture products $[14,15]$. One of the specified examples of this kind of natural ecosystem destruction is Tigris and Euphrates aquifers. It can be said that it is one of the largest destructors. The underlying area has witnessed more than 60 types of engineering projects during 3 last decades (including dam construction, or skewed channels to remove seasonal floods and using irrigate water of the lands). It resulted to the reduction of the entering water into the basin and its destruction which has reduced significantly its area $[9,17]$.

Hoor-Alazim pond is located at the west - east part of
Khuzestan province in Iran - Iraq boundary [10]. Karkheh River which originated from Lorestan Mountains, after considerable distance in Azadegan plane and an area called Hamidieh the Karkheh noor branch separated of it and divides to two Hoofl and Nisan branches at Soosangerd city, each of these branches divides into several branches at Hoor. The area of the pond is influenced by flood regimens of Karkheh rivers in Iran and Tigris and Euphrates in Iraq $[1,4]$. About $\frac{2}{3}$ of the area is in Iraq and $\frac{1}{3}$ of it is in Iran, and it called Hoor AlHoveizeh in Iraq [11]. This pond is in $47^{0}$ longitudes and $31^{0}$ altitudes [20]. In 1377, Iran began to construct the largest dam on the Karkheh River. This is one of the biggest water resources of Hoor-Alazim lagoon that has been designed to irrigate 320,000 hectare lands of Khuzestan plane [16]. Jone et al. [2005] reported that the area of Mesopotamia marshy lands which have been more than $8000 \mathrm{~km}^{2}$ in 1966 have decreased to about $750 \mathrm{~km}^{2}$ in 2002. Jamei et al. [2006] using remote 
techniques measured that the area of Hoor-Alazim ponds has decreased from 1991 to 2002 . According to them, the ponds area has decreased from $900 \mathrm{~km}^{2}$ in 1991 to $400 \mathrm{~km}^{2}$ in 2003 [2]. This study was performed to investigate the quantitative transformations of the entering waters into the Hoor-Alazim pond during a statistical period, and also to study the entering flow into the pond before and after the exploitation of Karkheh dam. Although there have been some studies about quantitative changes of the entering water values to the pond, so far there hasn't been a study considering the impact of this trend on the area of Hoor-Alazim pond.

\section{Material and Method}

\subsection{The Studied Area}

The studied area is a part of Karkheh River basin located at the end of it. Karkheh is the third full-water river of the country that is one of the most important rivers of the aquiferous basins of the Persian Gulf. The Karkheh lops runoff a wide area of Ilam, Kermanshah, Lorestan, Hamedan and limited areas of Kurdistan and Khuzestan, then enter its into Khuzestan plain passing Bakhtar Dezful Shosh, Soosangerd and Boostan cities, and enters into Hoor-Alazim pond along with some branches. The basin area is about 50727 $\mathrm{km}^{2}$. This river doesn't enter into the Persian gulf directly rather it first enter into Hoor-Alazim then communicates the Persian gulf via Arvand River [2, 18].

\subsection{Hydrometric Station}

In this study the data from 3 hydrometric stations at the end of the Karkheh watershed basin were used. Table (1) shows the geographical coordinate systems of the selected hydrometric stations of this study. The number of used years to study the entering water into the pond is 52 ones during $1987-2009$. In addition to the mentioned hydrometric station in tablet the recorded rainfall data in Hamidieh rainfall-metric station were used.

In this study the flow position in Hydrometric stations was studied in two months and yearly time scales. In general, the below steps were followed:

1) Providing water entering set in monthly and yearly scales using Excell software.

2) Independent - sample T test of the rainfall before and after the construction of Karkheh dam, using SPSS software.

3) Independent - sample $T$ test of the Karkheh water entering before and after Karkheh construction, using SPSS software.

Table 1. Selective correlations of Hydrometric stations

\begin{tabular}{llll}
\hline Neisan & Hufel & Hamidieh & Station identity data \\
\hline $48^{\circ}-11^{\prime}-40^{\prime \prime}$ & $49^{\circ}-49^{\prime}-30^{\prime \prime}$ & $50^{\circ}-70^{\prime}-26^{\prime \prime}$ & Length \\
$31^{\circ}-34^{\prime}-34^{\prime \prime}$ & $31^{\circ}-03^{\prime}-20^{\prime \prime}$ & $31^{\circ}-46^{\prime}-19^{\prime \prime}$ & Wide \\
13.97 & 12.61 & 24.5 & Height (m) \\
1987 & 1987 & 1955 & Establishment year \\
\hline
\end{tabular}

\subsection{Pond Extraction Using Remote Measurement}

To assess the watery and plant covering surfaces of the pond the data from three sets of Landsat satellite 7-images with following characteristics were used:

1) Landsat TM measurement block 38 - 164, in May 1991

2) Landsat ETM measurement block 38 - 164, in May 2002

3) Landsat TM measurement block 38 - 164, in August 2009.

It is worth noting that the used software in this section includes:

ENVI 4 software to process images, radiometric and geometric correctness and classification. Arc GIS software to measure area, and extracted layers of the environment.

\section{Discussion and Results}

Regarding the research objective, at first the flow regimen at the end of the Karkheh basin has been studied. (1), (2), (3) diagrams show the yearly water entering set of changes in the hydrometric station. The river water entering has been decreased over time. This reduction has been significantly from 1998 - 1999 years (during Karkheh exploitation).

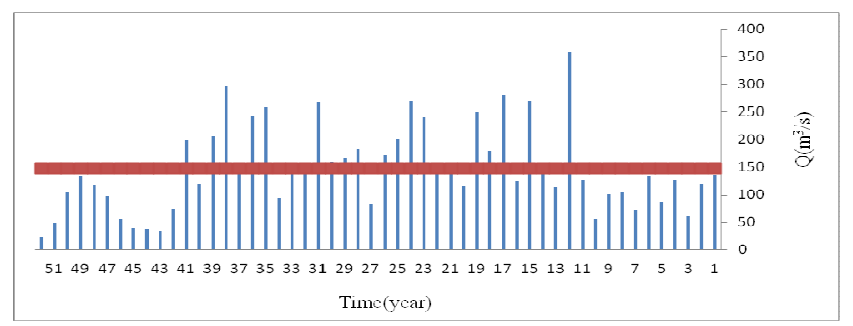

Diagram (1). The mean annual water entering series of changes in Hamidieh Hydrometric station.

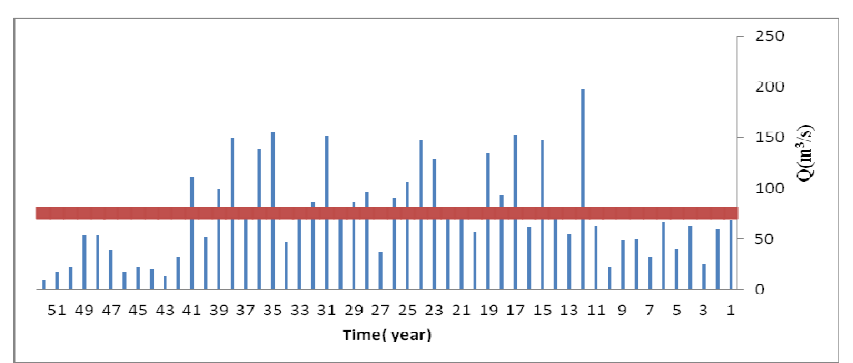

Diagram (2). The mean annual water entering series of changes in Hufel Hydrometric station

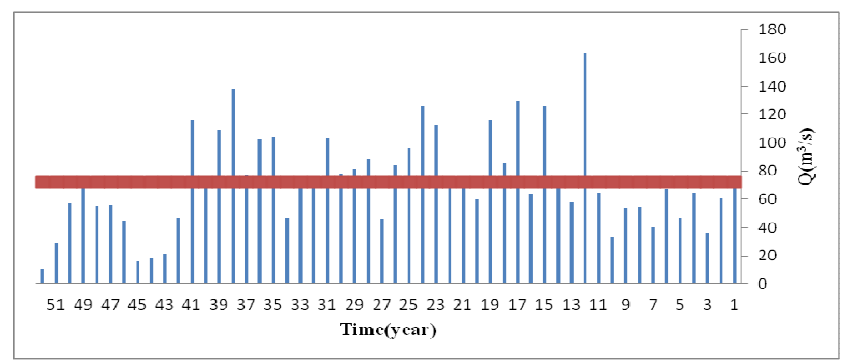

Diagram (3). The mean annual water entering seriesof changes in Neysan Hydrometric station 
A summary of water entering and mean rainfall comparison test is shown in table (2). In this table, the comparing means include time series of rainfall and water entering for two statistic periods before (1987 - 1998), and after Karkheh dam exploitation (1998 - 2009).

The means of the rainfall time series for the period before and after Karkheh exploitation were 179 and $249 \mathrm{~mm}$, respectively. The difference was at the statistical level of $1 \%$. The water entering means before and after dam exploitation were 168 and $69 \frac{\mathrm{m}^{3}}{\mathrm{~s}}$, respectively.

The partial difference in the water entering mean is more than rainfall mean differences. This indicates that water entering mean differences are affected by rainfall changes and Karkheh savings. As table (3) shows to clarify the weight of difference between rainfall and entering flow means, the simultaneous data of rainfall in Hamidieh meteorologic station and flow in its hygrometric station after Karkheh exploitation $(1998$ - 2009) were in non-dimensional order. The non- dimensional ratio of these time series resulted from dividing each year to their means is as the following ratio: $\left(\frac{P}{P}\right)$ and $\left(\frac{Q}{Q}\right)$. Results from simultaneous tests of these ratios in two separated groups show that the effect of the entering flow to the pond is higher than the rainfall. In other words, the weight of reservoir saving index is higher than the rainfall index in entering flow to the pond. Results of this study show that entering flow to the pond after dam exploitation has decreased sharply. The statistical analysis showed that the water entering value in selected hydrometric station, and also the rainfall rate during the study has decreased, but the reduction in water entering has been higher than rainfall.

Table 2. Results of statistical analysis in Hamideieh hydrometric stations.

\begin{tabular}{|c|c|c|c|c|c|c|}
\hline Variable & Satistical period & Number of years & Mean & Std. deviation & $\mathbf{F}$ & Sig \\
\hline \multirow[t]{2}{*}{${ }^{*}$ Rainfall } & $1966-1998$ & 32 & 249 & 85 & 25 & 0.007 \\
\hline & $1998-2009$ & 11 & 179 & 59.6 & & \\
\hline \multirow[t]{2}{*}{ *Entering flow } & $1987-1998$ & 41 & 167.63 & 72 & 31 & 0.00 \\
\hline & $1998-2009$ & 11 & 69.28 & 38 & & \\
\hline
\end{tabular}

*rainfall in terms of $(\mathrm{mm})$ and water entering in terms of $\mathrm{m}^{3}$.

Table 3. Results of statistical analysis of the simultaneous rainfall and water entering after dam exploitation in Hamidieh hydrometric and Metrologic stations.

\begin{tabular}{llllll}
\hline Variable & Satistical period & Number of the year & Mean & Std. deviation & F \\
\hline${ }^{*}$ Index Rainfall & $1998-2009$ & 11 & 0.77 & 0.25 & 20 \\
${ }^{*}$ Index Entering flow & $1998-2009$ & 11 & 0.47 & 0.25 & \\
\hline
\end{tabular}

*rainfall in terms of $(\mathrm{mm})$ and watering in terms of $\mathrm{m}^{3}$.

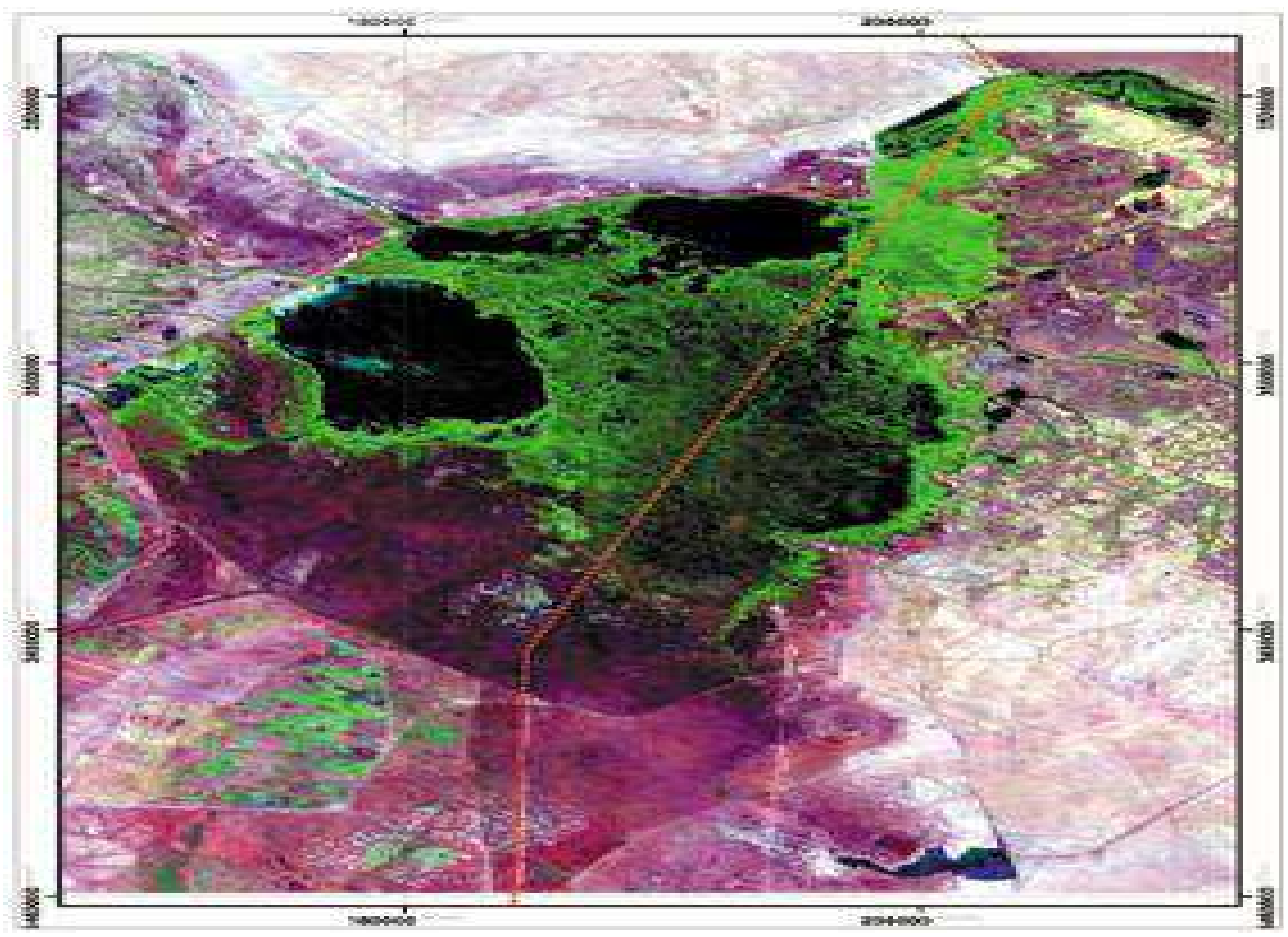

Figure (1). Lansat TM measuring image, during May 1991 


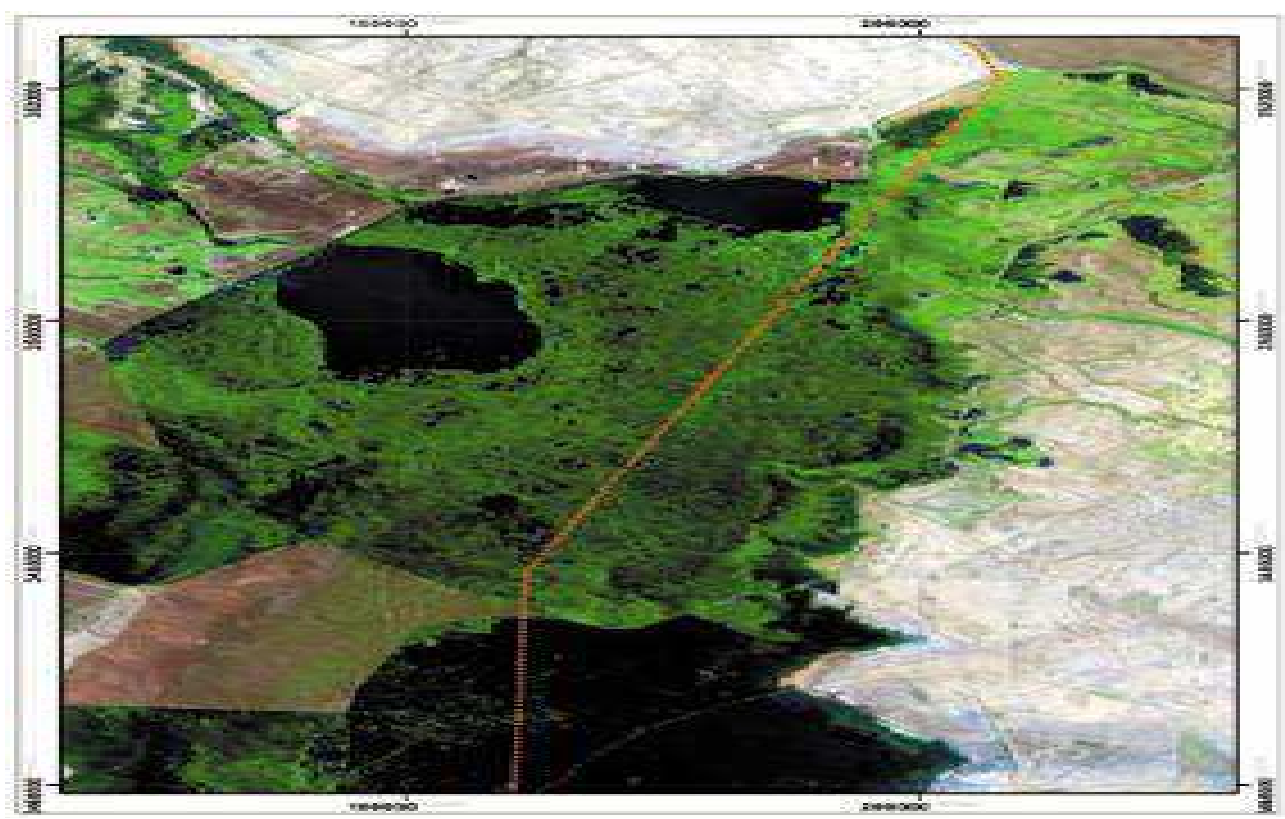

Figure (2). Landsat ETM+ measuring image, in May 2002

The pond surface changes. Figures (1) and (2) illustrated the Landsat TM measuring images during May 1991, and Landsat ETM during May 2002. It is indicated the pond water surface, and plant covering changes during these years. Based on the remote measurements, the vegetal plant mass observed in green and water observed in black. Also, the pond dry sections are in purple. As the figures shown, the area of the pond has decreased extremely from 1991 to 2002. Regarding the mentioned issues in previous sections, it can be said that the main reason of the area reduction is the decreased water entering into the pond, and also the decrease in its quality. Landsat TM measuring images during May 1991, and Landsat ETM + measuring during May 2002 have been displayed that indicate the changes in water and vegetation level of the pond during these years. Figure (3) shows the measuring image during August 2009 that displays the change in water level and vegetation, in this figure the specificity of the images is higher because of its newness. Based on the above mentioned topics the main cause of the pond area reduction is the reduction of the entering water.

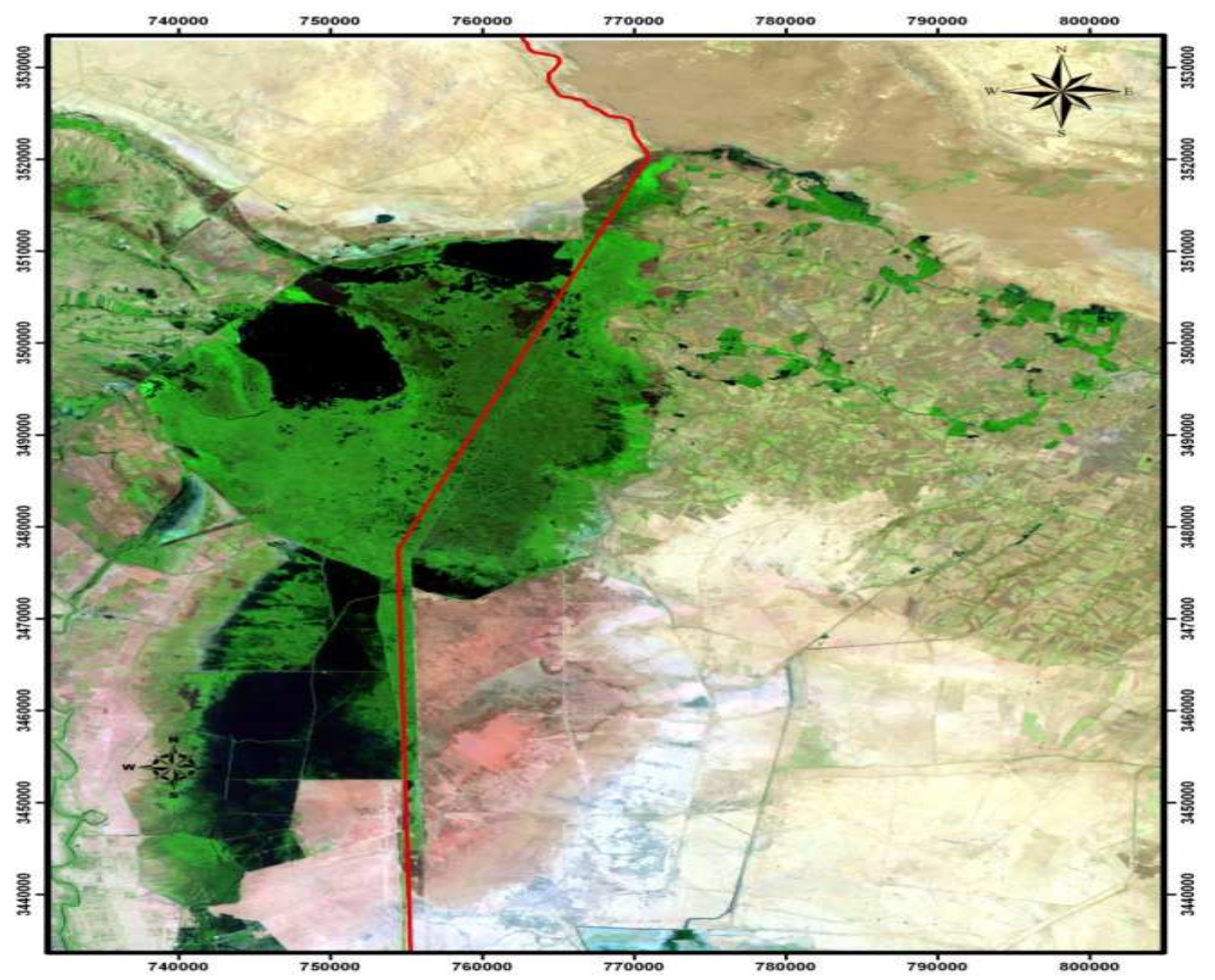

Figure (3). Landsat ETM+ measuring image, in August 2009 
Table (4). Hoor-Alazim vegetative and watery bulk areas $\left(\mathrm{Km}^{2}\right)$

\begin{tabular}{llll}
\hline Time of sat. transition & Vegetative bulk & Watery bulk & Sum \\
\hline 1991 & 583.5 & 317.5 & 901 \\
2002 & 180.5 & 217.2 & 397.2 \\
2009 & 269.12 & 21.81 & 290.93 \\
\hline
\end{tabular}

In Table (4) Hoor-Alazim pond vegetation and watery mass based on the data from remote measurement techniques are presented. Results show that the area in '81 year has reduced from 1991. The pond area has reached from $900 \mathrm{~km}^{2}$ in 1991 to $300 \mathrm{~km}^{2}$ in 2009 .

\section{Conclusions}

Hoor-Alazim is served as a local and natural native environment and it is one of the most important and various ponds in the world, because of some incorrect human policies such as dam construction, and also natural unfavorable elements and feeding river pollutions, the pond is seemingly eroding and gradually becomes smaller and more unstable. Also the studies by Jones et al. (2005) showed that dam construction on the river paths have caused a reduction in area by $85 \%$ [9]. Ghobadi et al. (2012) also indicated that $72 \%$ reduction in area induced by increase in agricultural lands, demands for water and man interference in high area of the pond [21]. Results showed that the main reason of reduction in the area is the reduction in the water entering into the pond because of the Karkheh tankage. As the rainfall rate has not significantly changed during last years, the water entering into the pond has decreased considerably.

\section{References}

[1] Augustine M.F., Warrender C.E, 1998, Wetland classification usingoptical and radar data and neural network classification, Int. J. of Remote Sensing. Vol. 19, pp. 1545-1560.

[2] Chen, X., 2002, Using remote sensing and GIS to analyze land cover changeand its impacts on regional sustainable development, Int. J. RemoteSensing, Vol. 23, pp. 107-124.

[3] Clark, P., and Magee, S, 2002, The Iraqi Marshland (A Human and Environmental Study), Amar International Charitable Foundation London, UK, pp. 20-27.

[4] Coppin, P., Jonckheere, I., Nackaerts, K., Muys, B., and Lambin, E., 2004, Digital change detection methods in ecosystem monitoring; a review, International Journal of Remote Sensing. Vol. 25, pp. 1565-1596.

[5] Dugan, P.J (ed), 1993, Wetland Conservation: a Review of Current Issue and Required Action, Vol. 1, first ed., IUCN/Gland, Switzerland, pp. 65-70.

[6] Friedl, G., Wuest, A., 2001, Southeastern Anatolia Project in Turkey - GAP. Seminar for Doctoral Students at the ETH Zurich, pp. 21-24.

[7] Friedl, G., and Wuest, A, 2001, Southeastern Anatolia Project in Turkey-GAP, Seminar for Doctoral Students at the ETH Zurich,

pp.

21-24. http://www.eawag.ch/research_e/apec/damsworldwide_e.html.

[8] Ghobadi, Y., Pradhan, B., Kabiri, K., Pirasteh, S., Shafri, H. Z.M., and Sayyad, G. A., Use of Multi-Temporal Remote Sensing Data and GIS for Wet land Change Moni tor ing and Degradation, IEEE Colloquim on Humanities, Science \& Engineering Research (CHUSER 2012), December 3-4, 2012 Kota Kinabalu, Sabah, Malasia (2012).

[9] JAMAB, 1999, Comprehensive assessment of national water resources: Karkheh River Basin, JAMAB Consulting Engineers in Association with Ministry of Energy, Iran (In Persian).

[10] JAMAB, 2006, Water balance report of Karkheh River Basin area: preliminary analysis, JAMAB Consulting Engineers in Association with Ministry of Energy, Iran.

[11] Jamei, M., 2003, Introducing the Khuzestan Wetlands and estuaries, first ed., Water Research Council Publications, Khuzestan Water and Power Authority, pp.39-44.

[12] Jamei, M., Hemadi, K., Hosein Zadeh, M., 2010, Assessment of water resources Hoor-Alazim wetland in order to use in the land-use plans with the techniques of remote sensing (RS), Article Summaries of the First National Conference on Water Resources Management in coastal areas, Sari Agricultural Sciences and Natural Resources University, Water Science Engineering Department, pp. 52-66

[13] Jones, C.K., Sultan, M., Al-Dousari, A., Salih, S.A., Becker, R. and Milewski, A., 2005, Who did what to the Mesopotamian Marshlands? Inferences from Temporal Satellite Data. The Proceedings of Annual Meeting of Geological Society of America Programs, 37(7), pp. 231-6.

[14] Jones, C., Sultan, M., Yan, E., Mileweki, A., Hossein, M., Al-Dousari, A., Al-Kaisy, S., and Becker, R., 2008, Hydrological impacts of engineering projects on the Tigris-Euphrates system and its marshlands, Hydrology, 353, pp. 59-75.

[15] Masih, M. D. Ahman. S. Uhlenbrook, H. Turral, and P. Karimi, 2009, Analyzing stream flow variability and water allocation for sustainable management of water resources in the semi-arid Karkheh river basin, Iran, Physic and Chemistry of the Earth, Vol. 34, pp. 329-340.

[16] Meghdad, A., 1998, Water Quantity in Border Marshlands between Iran and Iraq, Vol. 1, first ed., Baghdad University, Baghdad, pp. 104-108.

[17] Mokhtari, S., Soltani, H., Yavari, A., 2009, Self Organizing at Hoor-Alazim/ Hoor Alhoviezeh wetland with emphasis on ecology Landscape, Journal of Natural Geography Researches, No. 70 , pp. 93-105.

[18] Ramesht, M., H., 1987, Natural Geography Hoor-Alazim, first ed, Art Publications, Tehran, pp. 15-24.

[19] Shabankari, M., Halbian, A.H., 2007, Studying the process of degradation, instability and ecological changes of Hoor-Alazim wetland. Humans and Environment, No. 5, pp. 31-44.

[20] UNEP, 2001, The Mesopotamian Marshlands: Demise of an Ecosystem Early Warning and Assessment Report, UNEP/DEWA/TR.01-3 Rev.1. Division of Early Warning and Assessment, United Nations Environmental Programe, Nairobi, Kenya. 
[21] Zarasvandi, A., Carranza, E.J.M., Moore, F., Rastmanesh, F, 2011, Spatio-temporal occurrences and mineralogical-geochemical characteristics of airborne dusts in
Khuzestan Province (Southwestern Iran), Geochemical Exploration, 4884, pp. 2-14. 